\title{
STOCHASTIC SIMULATION AND VALIDATION OF MARKOV MODELS OF REAL DRIVING CYCLES
}

\author{
Andrzej PUCHALSKI, Iwona KOMORSKA \\ University of Technology and Humanities in Radom, Radom, Poland, \\ andrzej.puchalski@uthrad.pl, iwona.komorska@uthrad.pl
}

\begin{abstract}
The driving cycle is a time series of the vehicle speed reflecting its movement in real road conditions. The WLTC (Worlwide harmonized Light duty Test Cycle) valid from August 2017 is based on real driving profiles derived from research and statistical analysis of road traffic in Europe, the USA and Asia. In addition to certification and comparative research, driving cycles are used in the process of virtual design of drive systems and embedded control algorithms, traffic management or intelligent road transport. Regardless of the intended use, the standard test does not guarantee the correctness of the results obtained. There is a need to generate many different driving cycles that meet the established equivalence conditions. The article discusses the methods of stochastic simulation and assessment of equivalence of obtained traffic models. The Monte Carlo method of Markov chains was used in the research. The comparative criteria are defined using the statistical parameters of the vehicle speed time series and the corresponding multifractal spectra. The synthesis was carried out at predetermined length of time series. The experiment carried out involved the study of traffic in real road conditions of urban driving and extra-urban large agglomerations during working days.
\end{abstract}

Keywords: modeling and simulation, signal analysis, driving cycles equivalence

\section{SYMULACJE STOCHASTYCZNE I WALIDACJA MODELI MARKOWA RZECZYWISTYCH CYKLI JEZDNYCH POJAZDÓW}

\section{Streszczenie}

Cykl jezdny to szereg czasowy prędkości pojazdu odzwierciedlający jego ruch w rzeczywistych warunkach drogowych. Obowiązujący od sierpnia 2017 roku test WLTC (Worlwide harmonized Light duty Test Cycle) bazuje na rzeczywistych profilach jazdy pochodzących z badań i analiz statystycznych ruchu drogowego w Europie, USA i Azji. Poza certyfikacją i badaniami porównawczymi cykle jezdne wykorzystywane są w procesie wirtualnego projektowania układów napędowych i wbudowanych algorytmów sterowania, zarządzania ruchem ulicznym lub inteligentnym transportem samochodowym. Niezależnie od przeznaczenia posługiwanie się standardowym testem nie gwarantuje poprawności uzyskanych wyników. Istnieje konieczność generacji wielu różniących się cykli jezdnych, spełniających ustalone warunki równoważności. W artykule omówiono metody symulacji stochastycznych i oceny równoważności uzyskanych modeli ruchu drogowego. W badaniach wykorzystano metodę Monte Carlo łańcuchów Markowa. Kryteria porównawcze zdefiniowano za pomocą parametrów statystycznych szeregów czasowych prędkości pojazdu oraz odpowiadających im widm multifraktalnych. Syntezę prowadzono przy założonej długości szeregów czasowych. Zrealizowany eksperyment obejmował badania ruchu w rzeczywistych warunkach drogowych jazdy miejskiej i pozamiejskiej dużej aglomeracji w czasie dni roboczych.

Słowa kluczowe: modelowanie i symulacja, analiza sygnałów, równoważność cykli jezdnych

\section{INTRODUCTION}

The driving cycle is a simulation of the movement of the vehicle represented by the time series of speed. Motor vehicle driving tests were developed in accordance with the principle of faithful time domain simulation based on actual usage data or the synthesis of the theoretical driving profile. The FTP 75 (Federal Test Procedure) cycle used for many years in the United States and JC08 (Japanese cycle) in Japan are examples of the first group. NEDC (New European Driving Cycle) used in Europe in its present form since 1997 is a synthetic cycle. The WLTC (Worlwide harmonized Light duty Test Cycle) test, effective since August 2017, resulting from the world-wide harmonized light vehicle testing procedure (WLTP) is based on real driving profiles from statistical research and analyzes $[9,14]$. Provides more reliable combustion results during the simulation of vehicle operating conditions on the dynamometer.

Driving cycles are used for virtual design, certification and comparative testing. In the first case, the simulation of real cycles allows 
optimization of the parameters of the designed propulsion system and control strategy for the set emission levels and fuel consumption. In the other two we get the possibility to carry out emission and fuel consumption tests in real road conditions. Other applications of driving cycles may be associated with the development of new standards for exhaust emissions and fuel consumption.

If the virtual design process of control systems in the vehicle use the standard driving cycles, even based on the actual driving profiles derived from statistical surveys, there is a risk of selecting the wrong parameters or even the structure of algorithms. A separate problem concerns artificial intelligence systems responsible for determining travel time or traffic management or intelligent traffic engineering. In such cases, it is necessary to build driving cycles for specific agglomerations and geographic regions. The process of the synthesis of driving cycles requires then not only the registration of data from vehicle traffic tests in real road conditions represented by urban and extraurban driving, but also the characteristics of the network of streets and roads in the region. Another application of real driving cycles concerns the design of power management algorithms, which is particularly important in the case of hybrid and electric vehicles $[2,5]$.

Regardless of the type of the phenomenon being studied, for the synthesis process being carried out, it is necessary to generate many different driving cycles, but at the same time representative of the simulated reality. An important task is also to reduce the simulation time while retaining the ability to test the desired parameters. In addition to reflecting the specific traffic conditions - urban area during peak hours, off-peak hours, extra-urban area, highways, it should be possible to simulate various driver behaviors or road incidents. This requires defining statistical criteria for the equivalence of cycles and developing a modification algorithm. The driving cycle comparative criteria are defined in terms of time, frequency or probabilistic process values (compliance tests). The method of generating pseudo-random realizations of the stochastic process modeling driving tests in accordance with the criterion of similarity of the amplitude-frequency characteristics of speed in test conditions and the actual use of the vehicle was proposed in [3]. The procedures combining stochastic processes and statistical methods in the analysis of vehicle motion dynamics equations represented by velocity and acceleration were based on the theory of Markov models [7, 8]. The threedimensional Markov chain used in the synthesis of driving cycles, taking into account additional road gradient [1].

In section 2, the process of stochastic simulations using Markov chains is discussed. Chapter 3 is devoted to the analysis of the collected data of the experiment in real conditions and generation of Markov cycles. Standard statistical measures of car speed were determined and a new, not used so far, statistical parameter representing the dynamics of vehicle motion - the width of multifractal spectrum - was proposed. Chapter 4 discusses the process and criteria for testing the equivalence of obtained traffic models in terms of preserving the possibility of testing the desired parameters. The paper is concluded in Section 5.

\section{MODELS OF MARKOV CHAINS IN MONTE CARLO SIMULATION OF DRIVING CYCLES}

Monte Carlo simulations (MCs) are stochastic techniques, which means that they are based on the use of random numbers and probability statistics to investigate processes. Markov chain is the process wherein the computation of the future value of the random variable based on the current value, irrespective of the previous value.

In mathematical terms, the random process $X=\left\{X_{1}, X_{2}, X_{3}, \ldots\right\}$ in the discrete space of states $E$ is the first order Markov chain, if for each $j \in E$ and $n=0,1,2, \ldots$ conditional distribution $X_{n+1}$ is a function of the $X_{n}$ variable only:

$$
\begin{aligned}
& \operatorname{Pr}\left\{X_{n+1}=j \mid X_{0}=i_{0}, X_{1}=i_{1}, \ldots, X_{n}=i_{n}\right\}= \\
= & \operatorname{Pr}\left\{X_{n+1}=j \mid X_{n}=i_{n}\right\}
\end{aligned}
$$$$
\text { for each set of states } i_{0}, i_{1}, \ldots, i_{n} \text {. }
$$

If the Markov chain is stationary, with probabilities not changing with respect to time, the distribution of probabilities of transitions between particular kstates can be presented as a matrix, called the transition probability matrix (TPM) $P \in R^{k x k}$. It is a stochastic matrix:

$$
P=\left[\begin{array}{ccc}
P_{11} & \cdots & P_{1 k} \\
\vdots & \ddots & \vdots \\
P_{k 1} & \cdots & P_{k k}
\end{array}\right]
$$

where the $P_{i j}$ is equal to the probability of transition from state $i$ to state $j$, when $\mathrm{j} \neq \mathrm{i}$ or remain in state $i$, when $j=i$. The probability $P_{i j}$ can be calculated using the following equation:

$$
P_{i j}=\frac{N_{i j}}{\sum_{j} N_{i j}}
$$

where $N_{i j}$ is the number of transitions from the state $i$ and to the state $j$. All entries of this matrix $P_{i j} \geq 0$ and the sum of the values of entries in each row, i.e. probabilities of remaining or leaving a given state, is equal to one.

Defined states represented by so-called modal cycles included registered vehicle traffic parameters for specific speed ranges, with constant speed and idling. For the designated TPM, the search for Markov models of driving cycles was carried out, with the assumed duration, using the Monte Carlo simulation [15]. Taking into account the multifractal properties of road tests based on statistical driving profiles from real studies [4, 12, 13], the multifractal spectrum of generated time series of the car's speed was also analyzed. If the singularity spectra of different signals have similar 
properties, statistical similarity also applies to the dynamics of the corresponding processes. The time series obtained on the basis of the Markov model and segmentation by velocity require smoothing using a low-pass filter. The algorithm used to generate driving cycles candidates using the first order Markov chains is shown in Fig.1.

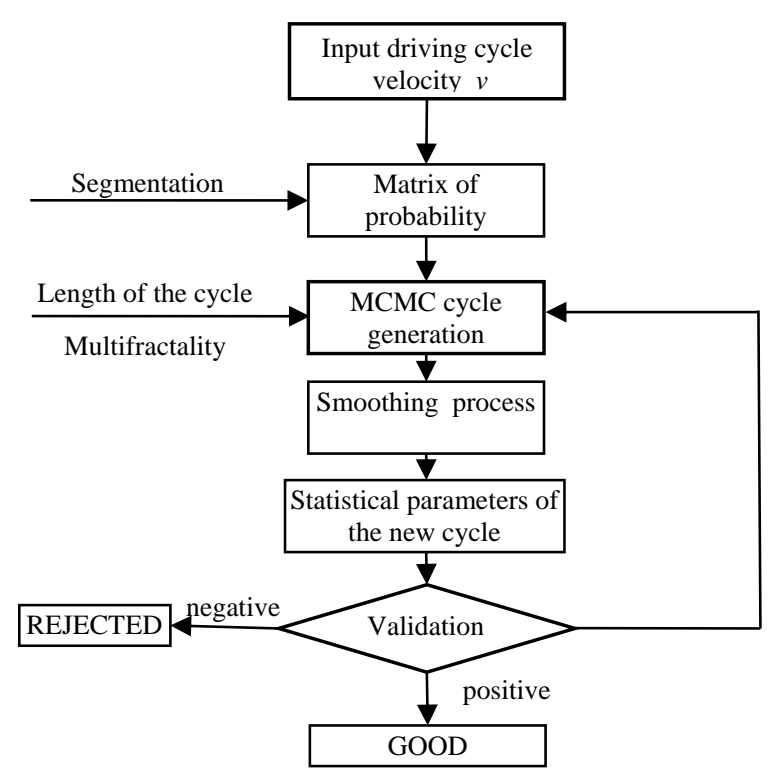

Fig. 1. An iterative algorithm for the generation of driving cycles using the stochastic simulation method

\section{EXPERIMENTAL DATA ANALYSIS}

The tests were carried out while driving on the streets of Radom at an acceptable speed of up to 50 $\mathrm{km} / \mathrm{h}$ and on the city's ring road at a speed of 70 $\mathrm{km} / \mathrm{h}$. Vehicle speed was recorded at 1 second intervals. The driving time lasts each time 1 hour. On the basis of the recorded speed signal (Fig.2), the velocity histogram shown in Fig.3 was determined.

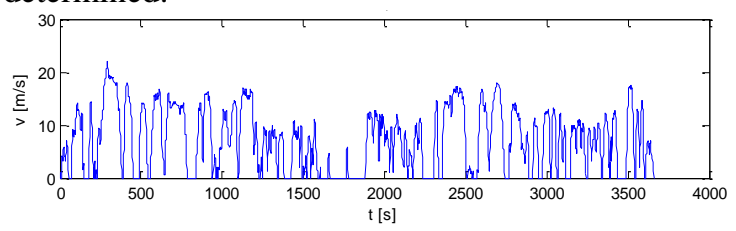

Fig. 2. Example of real-world driving cycle velocity of a car

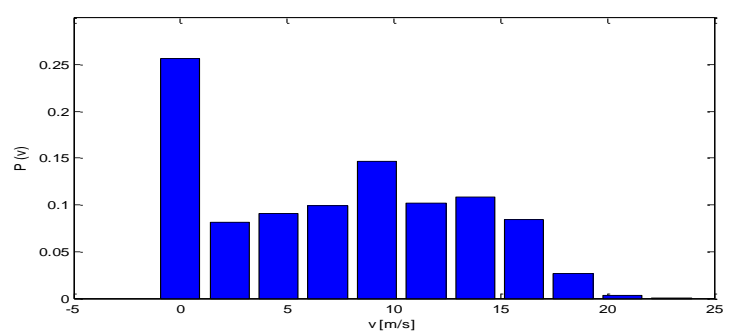

Fig. 3. Distribution of probability of vehicle velocities during the test
Due to the large percentage of the idling segment "zero speed" (about 25\% of the test time) - idle period was separated in the quantization process. Next, the vehicle speed was quantized for 10 subsets with a resolution of $2.3 \mathrm{~m} / \mathrm{s}$ and the transition probability matrix $P \in R^{11 \times 11}$ for 11 states was determined.

$P=\left[\begin{array}{ccccccccccc}0.94 & 0.04 & 0.02 & 0 & 0 & 0 & 0 & 0 & 0 & 0 & 0 \\ 0.23 & 0.58 & 0.18 & 0.01 & 0 & 0 & 0 & 0 & 0 & 0 & 0 \\ 0 & 0.20 & 0.60 & 0.02 & 0 & 0 & 0 & 0 & 0 & 0 & 0 \\ 0 & 0 & 0.18 & 0.62 & 0.20 & 0 & 0 & 0 & 0 & 0 & 0 \\ 0 & 0 & 0 & 0.14 & 0.72 & 0.14 & 0 & 0 & 0 & 0 & 0 \\ 0 & 0 & 0 & 0 & 0.17 & 0.72 & 0.11 & 0 & 0 & 0 & 0 \\ 0 & 0 & 0 & 0 & 0 & 0.10 & 0.83 & 0.07 & 0 & 0 & 0 \\ 0 & 0 & 0 & 0 & 0 & 0 & 0.10 & 0.84 & 0.06 & 0 & 0 \\ 0 & 0 & 0 & 0 & 0 & 0 & 0 & 0.09 & 0.90 & 0.01 & 0 \\ 0 & 0 & 0 & 0 & 0 & 0 & 0 & 0 & 0.05 & 0.92 & 0.03 \\ 0 & 0 & 0 & 0 & 0 & 0 & 0 & 0 & 0 & 0.17 & 0.83\end{array}\right]$

The non-zero entries of Markov model transition probability matrix focused on and around the main diagonal. This result means that next to the current vehicle speed will most likely be in the same or adjacent segment as the current speed, and the probability of transition between distant states is very small.

As one of the parameters of the cycle generation algorithm, the width of the multifractal spectrum of car speed $d h(q)$ was also assumed. Permissible discrepancy between multifractality was assumed at $10 \%$. An example of a multifractal spectrum of registered speed signals is shown in Fig.4.

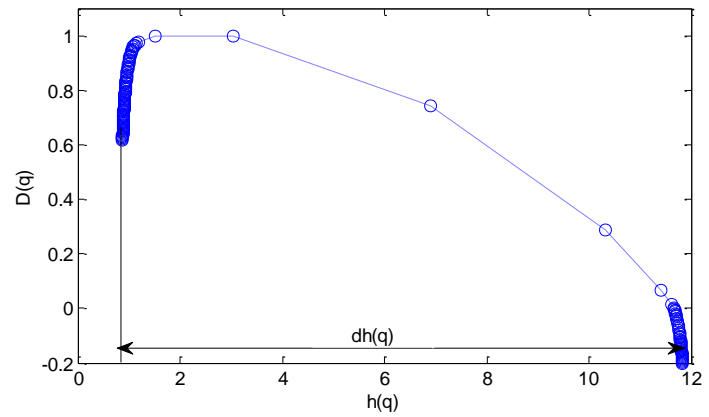

Fig. 4. Multifractal spectrum of real-world driving cycle

The confirmation of the strongly multifractal $[d h(q)>10]$ character of the analyzed real time series of vehicle speed was obtained. The most common singularity exponents concerned those fragments of registered time series, which describes the greatest variability. The lowest probability of registration showed periods of driving with the highest regularity. Most of the points is focused on the dimensions corresponding to the peculiarities of the largest and smallest fluctuation of the time series of vehicle speed.

For the needs of validation 5 statistical measures were defined and their values for the driving test in real conditions were calculated. 
Table 1. Statistical parameters characterizing the actual

\begin{tabular}{|c|c|c|c|c|}
\hline \multicolumn{4}{c}{ driving cycle } \\
\hline$v_{\max }$ & $v_{\text {std }}$ & $v_{a v}$ & $v_{\text {med }}$ & idle \\
\hline$[\mathrm{m} / \mathrm{s}]$ & {$[\mathrm{m} / \mathrm{s}]$} & {$[\mathrm{m} / \mathrm{s}]$} & {$[\mathrm{m} / \mathrm{s}]$} & {$[-]$} \\
\hline 21.94 & 5.79 & 7.21 & 7.22 & 0.24 \\
\hline
\end{tabular}

where:

$v_{\text {max }}, v_{s t d}, v_{a v}, v_{\text {med }}$ - maximum car speed, standard deviation, average vehicle speed, median vehicle speed, respectively,

idle - share of the car stop (car speed equal to 0 ) in the whole driving cycle

Based on the Markov model, 100 driving cycles were generated. Exemplary waveforms are shown in Fig. 5. In the analysis of the equivalence of the models of the dynamic of the road traffic, the time series of the speed of 1800 s were assumed.
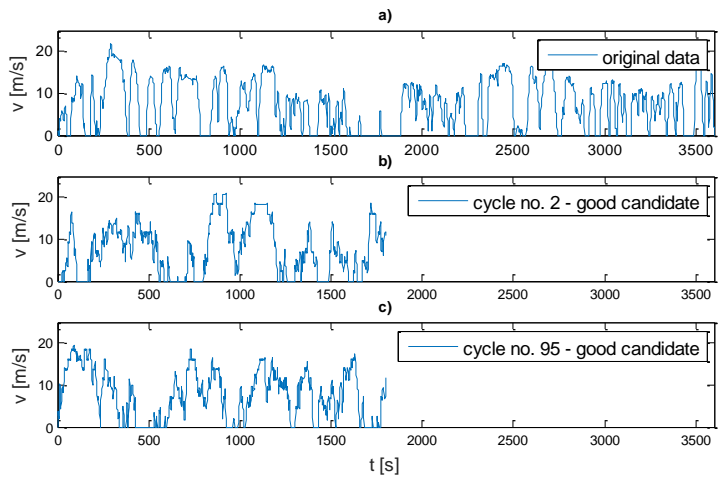

Fig. 5. The speed of the vehicle registered during a) the actual test and (b-c) two cycles generated on the basis of the Markov model

\section{ANALYSIS OF EQUIVALENCE OF ROAD MODELS}

Two methods were used to select the most representative cycles from all cycles obtained as a result of the Markov chain synthesis in the Monte Carlo experiment.

\section{Method I.}

On the basis of defined statistical measures of vehicle time series, the PV value - Performance value [6] was determined:

where:

$$
P V=\sum_{k} w_{k}\left|\frac{\text { synt } \text { par }_{k}-\text { oryg } \text { par }_{k}}{\text { oryg par }_{k}}\right|
$$

$k=5$, number of parameters,

$w_{k}$ - weight coefficients,

synt par $_{k}-k$-th parameter of the synthesized cycle,

oryg par $_{k}$ - $k$-th parameter of the real cycle.

The identical weighting factors of all statistical characteristics were adopted. The performance value (fig.6) were calculated for all candidate driving cycles, and the candidates with the lowest PV were selected as the final driving cycles for the particular vehicle.

The number of generated driving cycles, which can be considered equivalent to the real cycle, depends on their purpose and must be determined during experiments verifying the results of virtual design, certification or comparative testing.

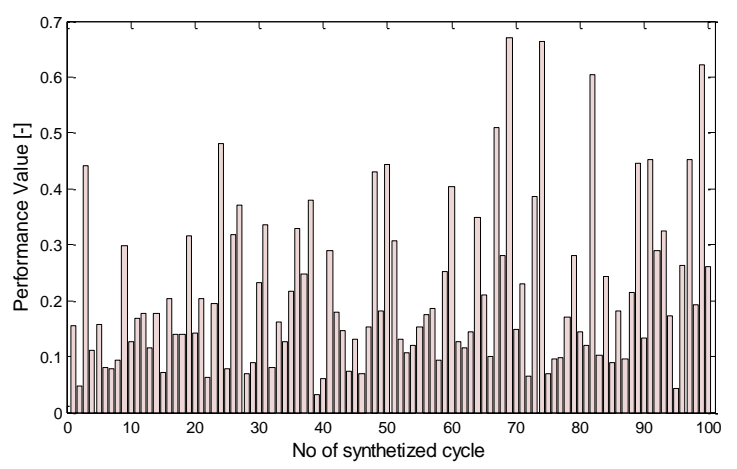

Fig. 6. PV indicators for generated driving cycles

Method II

The concept of equivalent driving cycles based on the Mean Tractive Force (MTF) [10,11] focuses on the estimation of the traction energy of the vehicle transmitted by the wheels during the driving cycle. The total tractive force, $\mathrm{F}(\mathrm{t})$, on the wheels consists of aerodynamic resistance, rolling resistance and inertia resistance.

$$
\begin{gathered}
F(t)=F_{\text {air }}+F_{\text {roll }}+m a(t) \\
F_{\text {air }}=0,5 \rho_{a} c_{d} A_{f} v^{2}(t) \\
F_{\text {roll }}=m g c_{r}
\end{gathered}
$$

where:

$F(t)$ - total tractive force,

$F_{\text {air }}$ - aerodynamic resistance,

$F_{\text {roll }}$ - rolling resistance,

$a(t)$ - vehicle acceleration,

$\rho_{a}=1.29 \mathrm{~kg} / \mathrm{m}^{3}$, air density,

$c_{d}=0.4$, drag coefficient,

$A_{f}=2 \mathrm{~m}^{2}$, frontal area,

$m=1100 \mathrm{~kg}$, vehicle mass,

$c_{r}=0.03$, rolling friction coefficient,

$g=9.81 \mathrm{~m} / \mathrm{s}^{2}$, gravitational constant.

After analysing the real routes, the impact of the driving profile was omitted, assuming that small uphill and downhill sections are compensated from the point of view of the energy demand during the whole cycle.

Since the drive system does not have to provide any forces to the wheels during runways or during periods of braking, the time intervals at which the Mean Tractive Force $\bar{F}_{\text {trac }}$ is calculated are those in which $F(t)>0$. $\bar{F}_{\text {trac }}$ is therefore defined on a subset:

by the formula:

$$
\tau_{\text {trac }}=\{\mathrm{t} \in \tau: F(t)>0\}
$$

$$
\bar{F}_{\text {trac }}=\frac{1}{x_{\text {total }}} \int_{t \in \tau_{\text {trac }}} F(t) v(t) d t
$$

where $v(t)$ is the instantaneous speed of the driving cycle.

The total traction force and time intervals at which the Mean Tractive Force is calculated is shown for the fragment of the generated run cycle 
in Fig. 7, and the distribution of MTF values for all tested cycles is shown in Fig.8.
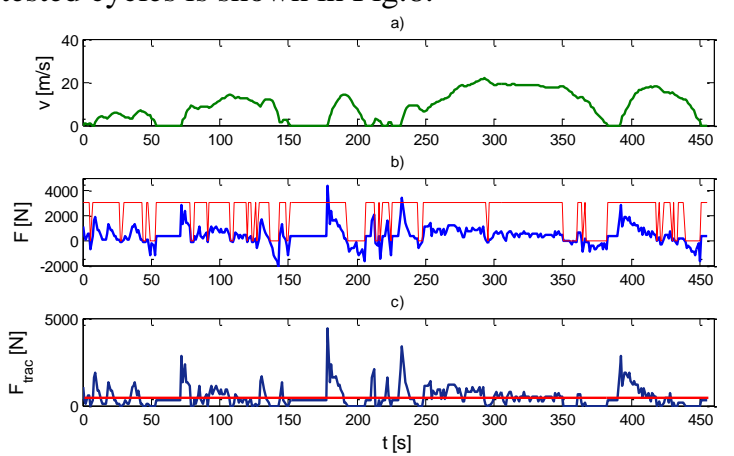

Fig. 7. Mean Tractive Force cycle analysis a) fragment of the cycle, b) the momentary value of the MTF with the time intervals in which the force is calculated, c) MTF instantaneous values and mean value

The observed discrepancy of MTF of generated cycles does not exceed $10 \%$ of the MTF value for the registered real driving cycle. The acceptable level of compliance of models equivalent to the real driving conditions should be determined according to the type and assumptions of the conducted analysis process.

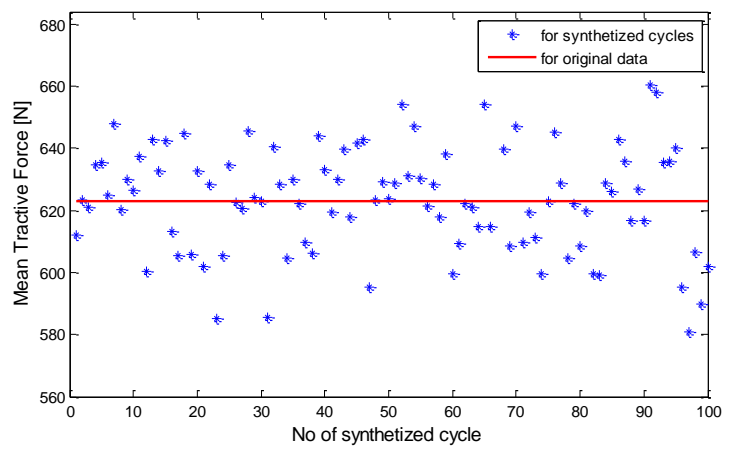

Fig. 8. Mean Tractive Force for 100 generated cycles and the real driving cycle

\section{CONCLUSIONS}

To achieve the representativeness of the synthesized driving cycles for vehicles, a sufficiently large and objective database, the simplicity and accuracy of the method and a stochastic, statistical synthesis algorithm are required. Time series were generated using onedimensional Markov chains based on the measurement of one physical quantity which is the speed of the car. Iteration in the Monte Carlo simulation was carried out for the assumed time, with the requirement concerning the driving dynamics determined by the multifractality level of the real driving experiment. Two measures were used for validation and selection of vehicle traffic conditions models, equivalent to real conditions: PV - Performance value and MTF - Mean Tractive Force.

Representative driving cycles, different from the standard cycles, are essential in the design of drive systems and energy management, especially for
PHEV and EV. The next step of the research will be verification of the generated driving cycles in the management of electrical energy of EV fleet belonging to the local transport company. Taking into account the fact that the demand for traction energy is also dependent on the vertical profile of the driving cycle, it is planned to extend the time series of the algorithm with data including the altitude.

\section{REFERENCES}

1. Zhao B, Hofman T, Lv C, Steinbuch M. Intelligent Synthesis of Driving Cycle for Advanced Design and Control of Powertrains. In: 2018 IEEE Intelligent Vehicles Symposium (IV). IEEE/ 2018: 1608-1613. https://doi.org/10.1109/IVS.2018.8500522.

2. Brady J, Margaret $\mathrm{O}$, Brady J, Margaret $\mathrm{O}$. Development of a driving cycle to evaluate the energy economy of electric vehicles in urban areas. Applied energy/ 2016; 177: 165-178.

3. Chłopek Z. Synthesis of driving cycles in accordance with the criterion of similarity of frequency characteristics. Eksploatacja i Niezawodność Maintenance and Reliability. 2016;18(4):572-577. https://doi.org/10.17531/ein.2016.4.

4. Dai M, Zhang C, Zhang D. Multifractal and singularity analysis of highway volume data. Physica A. $2014 ; 407$ : 332-40. https://doi.org/10.1016/j.physa.2014.04.005

5. Hongwen H, Jinquan G, Jiankun P, Huachun T, Chao S. Real-time global driving cycle construction and the application to economy driving pro system in plug-in hybrid electric vehicles. Energy. 2018;152:95-107. https://doi.org/10.1016/j.energy.2018.03.061

6. Hung WT, Tong HY, Lee CP, Ha K, Pao LY. Development of a Practical Driving Cycle Construction Methodology: A Case Study in Hong Kong. Transportation Research Part D. 2007; 12: 115-128.

7. Hereijgers K, Silvas E, Hofman T, Steinbuch M. Effects of using Synthesized Driving Cycles on Vehicle Fuel Consumption. IFAC-PapersOnLine. 2017; 50(1): 7505-10. https://doi.org/10.1016/j.ifacol.2017.08.1183

8. Mayakuntlaa SK, Vermab A. A novel methodology for construction of driving cycles for Indian cities, Transportation Research Part D. 65, 2018: 725-735.

9. Mock $P$, Kühlwein $J$, Tietge $U$, Franco V, Bandivadekar A, German J. The WLTP: How a new test procedure for cars will affect fuel consumption values in the EU. In: The International Council on Clean Transpotration, Workink paper. 2014.

10. Nyberg P, Frisk E, Nielsen L. Generation of Equivalent Driving Cycles Using Markov Chains and Mean Tractive Force Components. Proc. of IFAC, 2014: 8787-8792.

11. Nyberg P, Frisk E, Nielsen L. Driving Cycle Adaption and Design Based on Mean Tractive Force. Proc. of IFAC. 2013;46(21):689-694.

12. Puchalski A, Ślęzak M, Komorska I, Wiśniowski P. Multifractal analysis vehicle's in-use speed profile for application in driving cycles. Eksploatacja i Niezawodność - Maintenance and Reliability 2018;20(2):177-181.

https://doi.org/10.17531/ein.2018.2.02 
13. Puchalski A, Komorska I. Binomial multifractal features of worldwide harmonized light duty vehicles test cycle. Vibroengineering Procedia. 2017;13:175179. https://doi.org/10.21595/vp.2017.19074

14. Sileghem L, Bosteels D, May J, Favre C, Verhelst S. Analysis of vehicle emission measurements on the new WLTC, the NEDC and the CADC. Transp Res Part D. 2014;32:70-85. https://doi.org/10.1016/j.trd.2014.07.008

15. Silvas E, Hereijgers K, Peng H, Hofman T, Steinbuch M. Synthesis of Realistic Driving Cycles with High Accuracy and Computational Speed, Including Slope Information. IEEE Trans Veh Technol. 2016; 65(6):4118-4128.

https://doi.org/10.1109/TVT.2016.2546338

Received 2019-03-08

Accepted 2019-06-13

Available online 2019-06-17

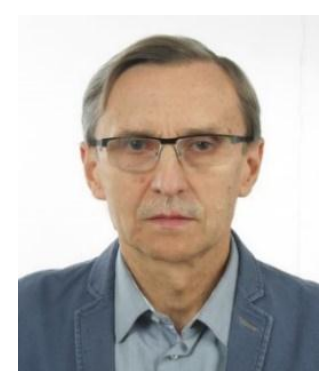

Andrzej PUCHALSKI received Ph.D. degree in Automatic Control and D.Sc. in Construction and Maintenance of Machines from Technical University of Warsaw. He works as Associate Professor at the Institute of Vehicles and Machines of UTH Radom. His main field of research includes technical diagnostics and mechatronics.

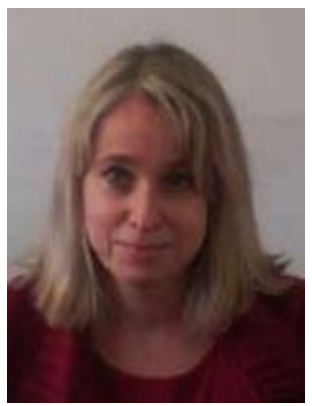

Iwona KOMORSKA received $\mathrm{PhD}$ degree in Faculty of Automotive and Construction Machinery Engineering from Warsaw University of Technology, Poland, in 1999.

The D.Sc. degree she received in Faculty of Mechanical Engineering and Robotics from AGH University of Science and Technology in Cracow, Poland, in 2014. Now she works as Associate Professor at Faculty of Mechanical Engineering at the University of Technology and Humanities in Radom, Poland. Her current research interests include data mining, modelling $\&$ simulation, mechatronics. 